\title{
Ирина БУКИНА
}

\section{БЮДЖЕТНО-НАЛОГОВАЯ ПОЛИТИКА РОССИИ В ПЕРИОД ЗАМЕДЛЕНИЯ ЭКОНОМИЧЕСКОГО РОСТА И ИТОГИ 2018 г.}

\begin{abstract}
Традиционно одной из задач бюджетно-налоговой политики является сглаживание последствий колебаний деловой активности. В связи с чем, в периоды спада последней должна проводиться стимулирующая политика, а в периоды подбема - сдерживающая. Бюджетно-налоговая политика в России, как показано в статье, носит преимущественно проциклический характер. В период спада 2015 г. по расчетам с использованием мультипликаторов государственные расходы скорее способствовали сокращению ВВП, чем поддержанию его роста. В дальнейшем, несмотря на значительное увеличение доходов бюджета расширенного правительства и смещение приоритетов с финансирования обороны и безопасности на социальную сферу, эффект от увеличения расходов бюджета оказался отрицательным. Автором рассматривается состояние бюджетной сферы по итогам 2018 г., который показал возобновление экономического роста.
\end{abstract}

Ключевые слова: бюджетно-налоговая политика, консолидированный бюджет РФ и бюджетов государственных внебюджетных фондов, мультипликатор, федеральный бюджет, экономическая политика, экономический рост, экономический цикл

JEL: E62, E64, H50, H60

Бюджетно-налоговая политика в развивающихся странах часто носит проциклический характер [1]. В периоды подъема деловой активности появляются средства для увеличения государственных расходов, в периоды спада - рост процентных ставок вынуждает их правительства сдерживать дефицит, поэтому расходы бюджета сокращаются. В России бюджетно-налоговая политика также является проциклической, в связи с чем сокращение бюджетных расходов на фоне спада деловой активности в 2015-2016 гг. служит яркой иллюстрацией данному утверждению. Однако судить о характере проводимой бюджетно-налоговой политики исключительно по динамике расходов некорректно. Ниже проводится как анализ динамики и структуры консолидированного бюджета РФ и бюджетов государственных внебюджетных фондов, так и оценка влияния изменения бюджетных расходов на ВВП с использованием фискальных мультипликаторов. 


\section{Бюджетно-налоговая политика в 2015-2018 г2.}

Замедление экономического роста в России наблюдалось уже с 2013 г. Однако в 2015 г. политические события и спад на сырьевых рынках спровоцировали рецессию в российской экономике: ВВП снизился на $2,5 \%$ по сравнению с 2014 г. В 2016 г. темпы роста оставались близки к нулю. В 2017-2018 гг. - около двух процентов. Таким образом, за 4 года российская экономика выросла лишь на 1,6\%1.

Колебания цен на нефть за последние четыре года характеризовались очень высоким разбросом значений. Из рисунка 1 видно, что изменение цены нефти сорта «Юралс» относительно показателя за аналогичный квартал предыдущего года составило от $-60,0$ до $+60,0 \%$. Тем не менее шоки такой силы не оказывали разрушительного воздействия на динамику выпуска.

На рисунке 1 представлена динамика показателя, который можно назвать производительностью труда. Это отношение ВВП к численности занятых за соответствующий квартал года. Колебания данного показателя в целом повторяют динамику цены нефти, однако его изменчивость невелика. На рисунке 1 темпы прироста производительности труда отмечены по правой оси, поскольку в некоторые периоды времени они на порядок отличались от темпов прироста цен на нефть.

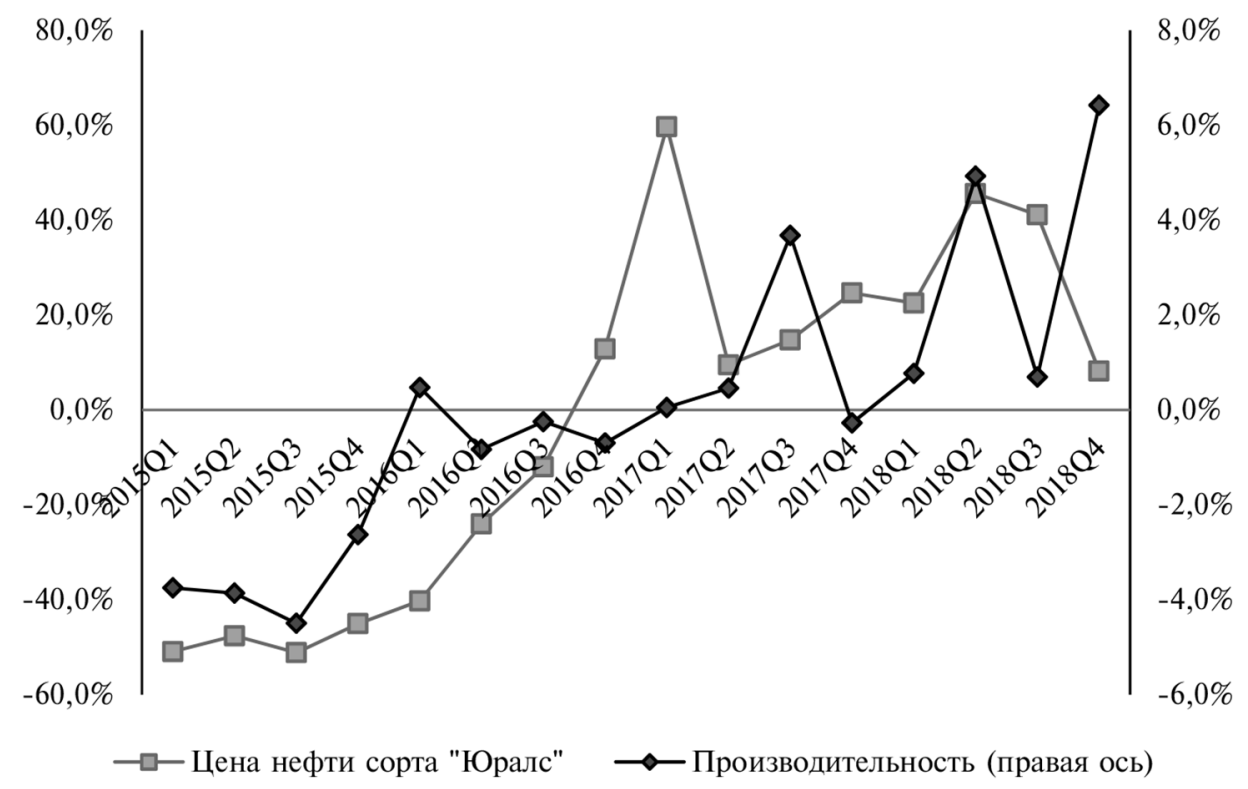

Рис. 1. Динамика цены нефти сорта «Юралс»

и производительности труда (в тыс. руб./чел.), в \% к аналогичному кварталу предыдущего года

Источник: URL: http://www.gks.ru; Данные, применяемые для расчета налога на добычу полезных ископаемых в отношении нефти и газового конденсата: справочная информация / СПС «КонсультантПлюс»; расчеты автора.

\footnotetext{
${ }^{1}$ URL: http://www.gks.ru; расчеты автора.
} 
В I-IV кварталах 2015-2018 гг. динамика производительности труда изменялась почти всегда в том же направлении, что и цена нефти. Однако строгой пропорциональности между динамикой этих показателей не наблюдается. Так, с III квартала 2015 г. по I квартал 2016 г. динамика производительности труда уже вышла на положительные значения, в то время как цена нефти сорта «Юралс» еще не достигла значений соответствующего квартала предыдущего года. В 2017 г., напротив, цена нефти росла быстрее, чем производительность труда.

Таким образом, за счет труда как фактора производства динамика ВВП остается более устойчивой к внешним шокам в краткосрочном периоде. Можно предположить, что данный фактор также обеспечивает большую стабильность доходных поступлений консолидированного бюджета РФ и бюджетов государственных внебюджетных фондов (бюджет расширенного правительства).

Табличиа 1

Доходы расииренного бюджета в 2015-2018 г2.

\begin{tabular}{|c|c|c|c|c|}
\hline & 2015 & 2016 & 2017 & 2018 \\
\hline \multicolumn{5}{|l|}{ Млрд руб. } \\
\hline Доходы - всего & 26494,09 & 27746,72 & 30640,02 & 36916,90 \\
\hline Нефтегазовые доходы & 5862,65 & 4844,03 & 5971,90 & 9017,77 \\
\hline \multicolumn{5}{|l|}{ Темпы прироста (год к году), в \% } \\
\hline Доходы - всего & $-4,01$ & $-0,64$ & 6,49 & 17,09 \\
\hline Нефтегазовые доходы & $-24,65$ & $-21,61$ & 18,89 & 46,75 \\
\hline \multicolumn{5}{|l|}{ Справочно: } \\
\hline $\begin{array}{l}\text { Прирост нефтегазовых доходов к приросту } \\
\text { ВВП }\end{array}$ & 0,81 & 0,78 & 1,17 & 1,43 \\
\hline $\begin{array}{l}\text { Доля нефтегазовых доходов к доходам - все- } \\
\text { го, в \% }\end{array}$ & 22,1 & 17,5 & 19,5 & 24,4 \\
\hline Доходы - всего к ВВП, в \% & 31,8 & 32,2 & 33,3 & 35,6 \\
\hline Нефтегазовые доходы к ВВП, в \% & 7,0 & 5,6 & 6,5 & 8,7 \\
\hline
\end{tabular}

Источник: URL: http://www.gks.ru; Отчеты об исполнении консолидированного бюджета РФ и бюджетов государственных внебюджетных фондов за 2015-2018 гг. URL: http:// www.roskazna.ru; расчеты автора.

Таблица 1 содержит данные о доходах расширенного бюджета, включая нефтегазовые доходы, которые в полной сумме поступают в федеральный бюджет. В 2015 г. отмечается наибольшее падение доходов. Причем нефтегазовые доходы сократились почти на четверть, в то время как общая сумма доходов бюджета расширенного правительства сократилась лишь на 4\%. В 2016 г. нефтегазовые доходы вновь сократились (на 21,6\%), однако общая величина доходов расширенного бюджета практически не менялась в сравнении с 2015 г. Номинально объем доходов даже несколько вырос, а с поправкой на потребительскую инфляцию (по ИПЦ) сократился менее, чем на $1 \%$. 
В 2017-2018 гг. картина зеркально поменялась: рост нефтегазовых доходов опережал рост общей суммы доходов бюджета расширенного правительства. Более того, к 2018 г. отношение нефтегазовых доходов к ВВП превышало аналогичный показатель 2015 г. и составило 8,7\%. При этом отношение доходов бюджета расширенного правительства к ВВП стабильно росло с 2015 г.

Сопоставляя данные таблищы 1 и рисунка 1, можно видеть, что колебания цен нефти в основном сказываются на динамике нефтегазовых доходов. Таким образом, федеральный бюджет позволяет частично абсорбировать влияние внешних шоков на состояние бюджетной системы РФ. Бюджет расширенного правительства в большей степени определяется динамикой производительности труда, нежели колебаниями цен нефти.

В целом сформированная система изъятия рентных доходов позволяет сохранять стабильность доходов бюджетной системы РФ, обеспечивая субъекты Федерации и внебюджетные фонды необходимыми средствами. Однако высокий уровень дифференциации доходов бюджетов субъектов РФ и зависимость от средств федерального правительства во многом нивелируют это преимущество.

Расходная часть бюджета расширенного правительства формируется, скорее, с учетом последнего замечания, а не в соответствии с закономерностями, описанными с помощью данных рисунка 1 и таблицы 1.

Из данных, представленных в таблице 2, следует, что расходы бюджета расширенного правительства в целом менялись незначительно. В 2016 и 2017 гг. они сокращались в реальном выражении, но менее, чем на 1\%. В 2018 г. расходы выросли почти на $3 \%$ в сопоставимых ценах 2017 г., притом что доходы бюджета расширенного правительства выросли на $17,1 \%$, обеспечив значительный профицит.

В таблице 2 расходы бюджета расширенного правительства сгруппированы не в соответствии с бюджетной классификацией, а с учетом их экономической роли. В строку «Общегосударственные расходы» включены также расходы по обслуживанию государственного и муниципального долга. Все расходы на «силовой блок» объединены в раздел «Национальная оборона, национальная безопасность и правоохранительная деятельность». Расходы на финансирование инфраструктуры и мер промышленной политики содержатся в разделе «Национальная экономика, ЖКХ, охрана окружающей среды». В разделе «Культура и социальная политика» сведены расходы, которые можно отнести к инвестициям в человеческий капитал. Это расходы на образование, здравоохранение, культуру, а также пенсионное обеспечение и прочие выплаты социального характера.

Общий секвестр был произведен в 2016 г., когда расходы сократились по всем категориям, за исключением расходов «силового блока». При этом в 2015 г., когда наблюдалось основное снижение ВВП и деловой активности в целом, расходы продолжали наращиваться (кроме расходов на национальную экономику и инфраструктуру).

В 2017-2018 гг. приоритеты сменились: росли расходы на социальную сферу и человеческий капитал, финансирование национальной экономики. Напротив, расходы на национальную оборону, национальную безопасность и правоохранительную деятельность резко сократились. 
Таблииа 2

Структура и динамика расходов бюджета расширенного правительства в 2015-2018 г2.

\begin{tabular}{|c|c|c|c|c|}
\hline & 2015 & 2016 & 2017 & 2018 \\
\hline \multicolumn{5}{|l|}{ В млрд руб. } \\
\hline Расходы - всего & 28646,9 & 30117,0 & 31147,4 & 32964,6 \\
\hline Общегосударственные вопросы & 2499,7 & 2621,7 & 2794,4 & 2131,5 \\
\hline $\begin{array}{l}\text { Национальная оборона, национальная без- } \\
\text { опасность и правоохранительная деятельность }\end{array}$ & 5254,9 & 5789 & 4888,3 & 4938,9 \\
\hline $\begin{array}{l}\text { Национальная экономика, ЖKX, охрана окру- } \\
\text { жающей среды }\end{array}$ & 4826,1 & 4966,4 & 5658,2 & 5915,2 \\
\hline Культура и социальная сфера & 16066,2 & 16739,9 & 17806,5 & 19978,9 \\
\hline \multicolumn{5}{|c|}{ Прирост в \% к предыдущему году (с поправкой на ИПЦ) } \\
\hline Расходы - всего & 2,55 & $-0,25$ & $-0,27$ & 2,85 \\
\hline Общегосударственные вопросы & 10,33 & $-0,49$ & 2,78 & 5,99 \\
\hline $\begin{array}{l}\text { Национальная оборона, национальная без- } \\
\text { опасность и правоохранительная деятельность }\end{array}$ & 7,43 & 4,52 & $-18,57$ & $-1,81$ \\
\hline $\begin{array}{l}\text { Национальная экономика, ЖКХ, охрана окру- } \\
\text { жающей среды }\end{array}$ & $-17,93$ & $-2,37$ & 9,86 & 1,60 \\
\hline Культура и социальная сфера & 7,84 & $-1,14$ & 2,58 & 4,04 \\
\hline
\end{tabular}

Источник: URL: http://www.gks.ru; Отчеты об исполнении консолидированного бюджета РФ и бюджетов государственных внебюджетных фондов за 2015-2018 гг. URL: http:// www.roskazna.ru; расчеты автора.

Воздействие расходов бюджета расширенного правительства на экономику можно оценить посредством мультипликаторов государственных расходов. Оценки мультипликаторов, как правило, осуществляются с помощью моделей авторегрессий. Особый интерес к использованию мультипликаторов бюджетно-налоговой политики возник после мирового финансового кризиса 2007-2009 гг. Так, одним из основных выводов стал эмпирический факт о том, что значения мультипликаторов увеличиваются в периоды спада деловой активности, что повышает эффективность инструментов бюджетно-налоговой политики в этот период [2].

Некоторые оценки мультипликаторов государственных расходов для России после 2008 г. свидетельствуют о том, что бюджетно-налоговая политика влияет на экономику в соответствии с теоретическими предположениями кейнсианской теории. Однако степень этого влияния, как правило, невелика. Так, по оценкам Центра макроэкономических исследований Сбербанка России, мультипликатор совокупных непроцентных расходов бюджета расширенного правительства составлял лишь 0,13 (для 2010 г.) [3].

Также оценки Центра макроэкономических исследований Сбербанка России показали, что для отдельных видов государственных расходов мультипликаторы могут быть больше, чем в целом по всей сумме. В частности, наибольший мультипликатор $(0,55)$ характерен для расходов на национальную экономику, ЖКХ и окружающую среду. 
На основе оценок Центра макроэкономических исследований Сбербанка России в настоящей работе было рассчитано влияние фактического изменения расходов бюджета расширенного правительства на ВВП России. Результаты этого расчета проиллюстрированы на рисунке 2.

Расчет учитывал изменение расходов относительно ВВП за 20152018 гг. и значение мультипликаторов госрасходов по состоянию на 2010 г.

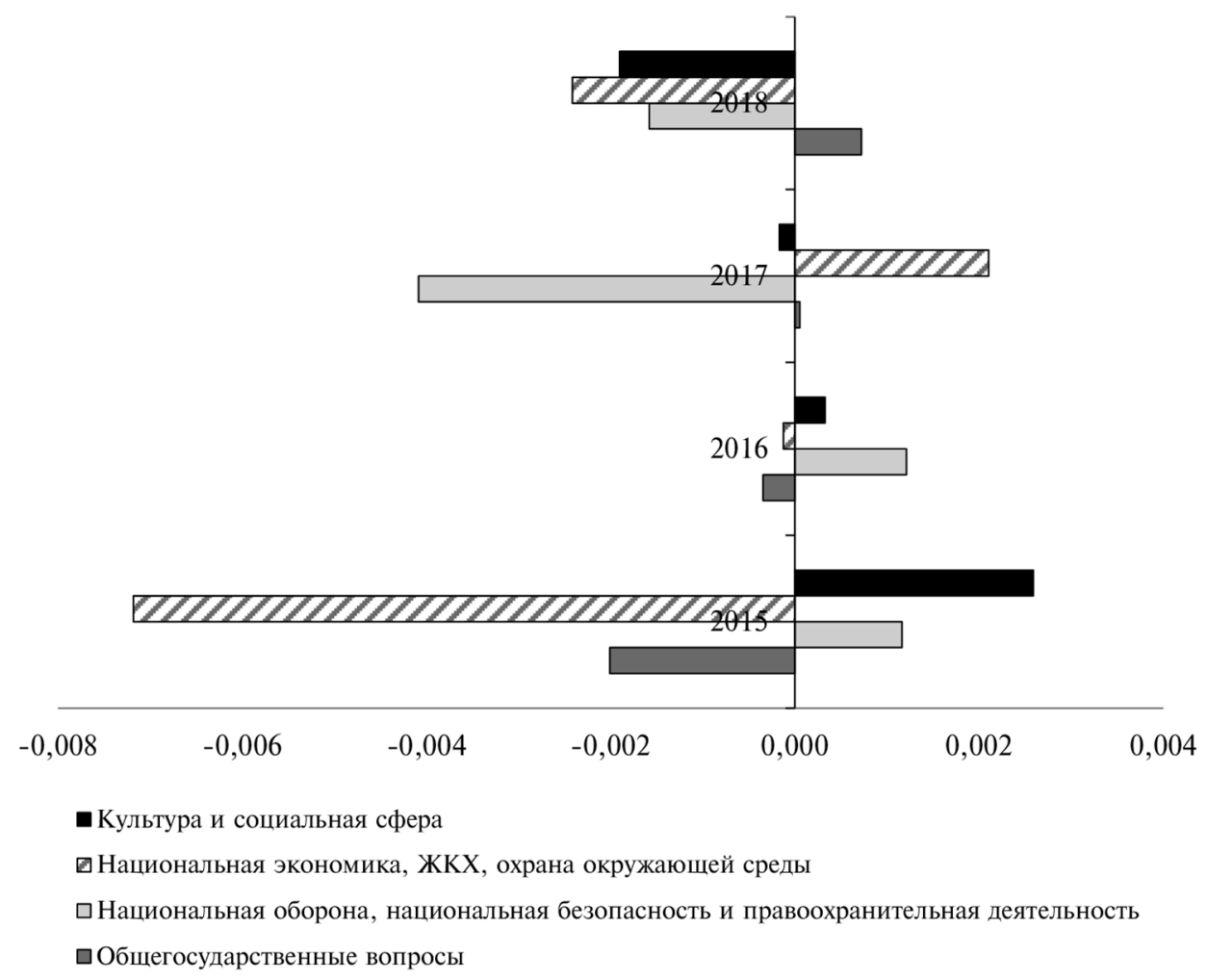

Рис. 2. Вклад изменения расходов бюджета расииренного правительства в прирост ВВП, в процентных пунктах

Источник: Эффективность госрасходов в России / Центр макроэкономических исследований Сбербанка России. 13.01.2011; Отчеты об исполнении консолидированного бюджета РФ и бюджетов государственных внебюджетных фондов за 2015-2018 гг. URL: http:// www.roskazna.ru; расчеты автора.

Согласно рисунку 2, изменения в расходах бюджета расширенного правительства в основном вносили негативный вклад в прирост валового выпуска. В 2015 г., несмотря на положительное влияние роста расходов на социальную сферу и национальную оборону, национальную безопасность и правоохранительную деятельность, сокращение расходов на национальную экономику, по сути, способствовало сокращению валового выпуска.

В 2016 г. происходило сокращение расходов относительно предыдущего года, однако относительно ВВП бюджетные расходы несколько возросли, поэтому мультипликативный эффект оказался в целом положительным, хотя и незначительно. 
В 2017 и 2018 г. опережающий рост ВВП привел к тому, что отношение расходов бюджета к выпуску сокращалось, поэтому влияние оказалось в основном отрицательным. В 2017 г. положительный вклад вносил рост расходов на национальную экономику, а в 2018 г. - рост расходов на общегосударственные вопросы.

Таким образом, наблюдаемый рост расходов, в том числе на цели развития человеческого капитала, может не вносить значимого вклада в рост ВВП, если последний происходит вследствие влияния благоприятной конъюнктуры. Проциклический характер бюджетно-налоговой политики России усиливает асимметричность действия мультипликаторов: усиливая их влияние в периоды замедления деловой активности и ослабляя, - в периоды ее оживления.

\section{Итоги 2018 г.}

Итоги 2018 г. оказались несколько выше скромных прогнозов Минэкономразвития. ВВП, по предварительной оценке, вырос на 2,3\% относительно 2017 г. Основной вклад в прирост валовой добавленной стоимости внесли добывающая промышленность, строительство, финансовая и страховая деятельность, сектор государственного управления. Рост совокупного спроса вновь поддерживался ростом цен на нефть: экспорт товаров по итогам 2018 г. почти на треть превысил аналогичный показатель за 2017 г. Рост инвестиций в основной капитал в январе сентябре 2018 г. составил 4,1\% в сравнении с аналогичным периодом 2017 г. При этом реальные располагаемые доходы населения выросли лишь на 0,3\% относительно 2017 г. Учитывая, что с 2014 г. реальные располагаемые доходы населения ежегодно снижались, слабый рост 2018 г. практически не повлиял на их уровень. К началу 2019 г. реальные располагаемые доходы населения составили лишь 90\% от уровня 2013 г.

В свою очередь доходы консолидированного бюджета РФ и бюджетов государственных внебюджетных фондов по итогам 2018 г. показали рост на $17,1 \%$ (с поправкой на потребительскую инфляцию). Всего в бюджеты бюджетной системы РФ и государственных внебюджетных фондов поступило 36 916,9 млрд руб. (см. табл. 3), что оценивается в 35,6\% к ВВП.

Структура доходов консолидированного бюджета РФ и бюджетов государственных внебюджетных фондов в 2018 г. изменилась - вновь за счет нефтегазовых поступлений. Увеличились доли налоговых доходов и неналоговых и прочих доходов в ущерб страховым взносам на обязательное социальное страхование. Удельный вес последних сократился с 21,3 до 19,5\%, хотя номинально поступления выросли до 7195,0 млрд руб. С поправкой на инфляцию прирост страховых взносов на обязательное социальное страхование составил 7,2\% в сравнении с предыдущим годом. Тем не менее это значительный рост, особенно в сравнении со скромными макроэкономическими показателями. Причина заключается в росте номинальной заработной платы, который по итогам 2018 г. оценивается в $109,9 \%$. Вновь наблюдается разрыв между стагнацией реальных располагаемых доходов населения и ростом реальной заработной платы (на $6,8 \%)$, превышающем темпы экономического роста. 
Таблии и 3

Доходы консолидированного бюджета РФ и бюджетов государственных внебюджетных фондов в 2017-2018 г2.

\begin{tabular}{|l|c|c|c|c|c|}
\hline \multirow{2}{*}{} & \multicolumn{2}{|c|}{2018} & \multicolumn{2}{c|}{2017} & $\begin{array}{c}\mathbf{2 0 1 8} \text { г. } \\
\text { к 2017 г. }\end{array}$ \\
\cline { 2 - 6 } & $\begin{array}{c}\text { млрд } \\
\text { руб. }\end{array}$ & $\begin{array}{c}\text { в \% } \\
\text { к итогу }\end{array}$ & $\begin{array}{c}\text { млрд } \\
\text { руб. }\end{array}$ & $\begin{array}{c}\text { в \% } \\
\text { к итогу }\end{array}$ & в \% \\
\hline Доходы бюджета & 36916,9 & 100,0 & 30640,0 & 100,0 & 117,1 \\
\hline В т.ч. & & & & & \\
\hline налоговые доходы & 23602,0 & 63,9 & 19277,6 & 62,9 & 119,0 \\
\hline $\begin{array}{l}\text { страховые взносы на обязательное } \\
\text { социальное страхование }\end{array}$ & 7195,0 & 19,5 & 6523,9 & 21,3 & 107,2 \\
\hline неналоговые и прочие доходы & 6119,9 & 16,6 & 4838,5 & 15,8 & 122,9 \\
\hline
\end{tabular}

Источник: URL: http://www.gks.ru; Отчеты об исполнении консолидированного бюджета РФ и бюджетов государственных внебюджетных фондов за 2017-2018 гг. URL: http:// www.roskazna.ru; расчеты автора.

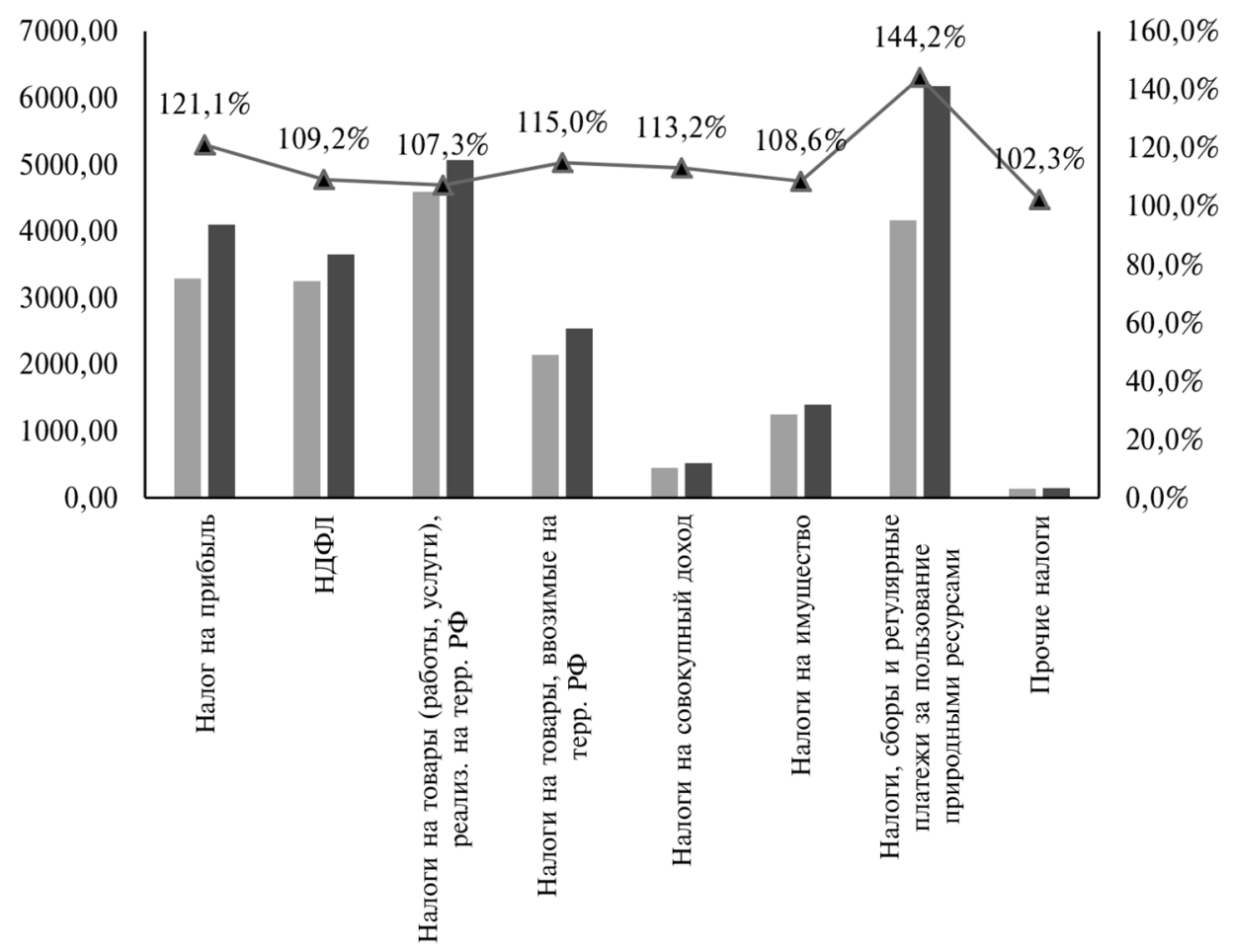

2017 г. 2018 г. \—2018 к 2017 г. в сопоставимых ценах, \%

Рис. 3. Динамика налоговых доходов консолидированного бюджета РФ и бюджетов государственных внебюджетных фондов в 2017-2018 г2.

Источник: URL: http://www.gks.ru; Отчеты об исполнении консолидированного бюджета РФ и бюджетов государственных внебюджетных фондов за 2017-2018 гг. URL: http:// www.roskazna.ru; расчеты автора. 
В структуре налоговых доходов также произошло некоторое перераспределение удельных весов. Впрочем, ожидаемое, поскольку, как видно из рисунка 3, благоприятная конъюнктура на рынке нефти обусловила опережающий рост поступлений от налогов за пользование природными ресурсами (на 44,2\%) и налога на прибыль организаций (на 21,1\%). В результате удельный вес налогов, сборов и регулярных платежей за пользование природными ресурсами в общей сумме доходов расширенного бюджета РФ вырос с 21 до 26\%. Безусловно, практически весь этот прирост был обеспечен поступлениями от налога на добычу полезных ископаемых в виде углеводородного сырья, т.е. основной выигрыш получил федеральный бюджет.

Вместе с тем отмечается и рост тех налогов, которые составляют основу бюджетов субъектов РФ. Помимо налога на прибыль речь идет о налоге на доходы физических лиц (далее - НДФЛ), поступления от которого выросли на $9,2 \%$, налогах на имущество $(+8,6 \%)$ и налогах на совокупный доход $(+13,2 \%)$.

В 2018 г. возобновился рост расходов бюджетов бюджетной системы РФ после периода экономии в условиях рецессии, снижения цен на нефть и политических санкций. Увеличение расходов было связано с выполнением «майских указов» 2012 г. в преддверии президентских выборов 2018 г. и проведения чемпионата мира по футболу.

Расходы консолидированного бюджета РФ и бюджетов государственных внебюджетных фондов в 2018 г. составили 33 880,7 млрд руб. и выросли на 2,9\% в сопоставимых ценах 2017 г. (по ИПЦ).

В 2018 г., в отличие от предыдущих лет, расходы на социальную политику практически не росли. Их удельный вес снизился с $36,3 \%$ в 2017 г. до 35,4\% в 2018 г. (см. табл. 4).

Табли и $а$ и 4

Структура и динамика расходов консолидированного бюджета РФ и бюджетов государственных внебюджетных фондов в 2018 г.

\begin{tabular}{|l|c|c|c|}
\hline \multicolumn{1}{|c|}{ Статьи расходов } & Млрд руб. & \% & $\begin{array}{c}\text { 2018 г. к 2017 г. } \\
\text { в сопоставимых } \\
\text { ценах, в \% }\end{array}$ \\
\hline Расходы - итого & 33880,7 & 100,0 & 102,9 \\
\hline Общегосударственные вопросы & 2131,5 & 6,3 & 106,1 \\
\hline Национальная оборона & 2828,4 & 8,3 & 96,3 \\
\hline $\begin{array}{l}\text { Национальная безопасность и правоохранительная } \\
\text { деятельность }\end{array}$ & 2110,5 & 6,2 & 100,8 \\
\hline Национальная экономика & 4442,9 & 13,1 & 99,7 \\
\hline Жилищно-коммунальное хозяйство & 1324,1 & 3,9 & 106,4 \\
\hline Охрана окружающей среды & 148,3 & 0,4 & 123,9 \\
\hline Образование & 3668,6 & 10,8 & 109,2 \\
\hline Культура, кинематография & 528,2 & 1,6 & 104,1 \\
\hline
\end{tabular}


Окончание табл. 4

\begin{tabular}{|l|c|c|c|}
\hline Здравоохранение & 3315,9 & 9,8 & 114,2 \\
\hline Социальная политика & 11998,2 & 35,4 & 100,4 \\
\hline Физическая культура и спорт & 331,5 & 1,0 & 98,5 \\
\hline Средства массовой информации & 136,5 & 0,4 & 104,2 \\
\hline $\begin{array}{l}\text { Обслуживание государственного и муниципального } \\
\text { долга }\end{array}$ & 916,1 & 2,7 & 105,8 \\
\hline $\begin{array}{l}\text { Справочно: } \\
\text { Профицит/дефицит }\end{array}$ & 3036,2 & & \\
\hline
\end{tabular}

Источник: URL: http://www.gks.ru; Отчеты об исполнении консолидированного бюджета РФ и бюджетов государственных внебюджетных фондов за 2017-2018 гг. URL: http:// www.roskazna.ru; расчеты автора.

Значительно выросли расходы на образование, доля которых составила более 10\%. Если в 2017 г. расходы на образование оценивались в 3264,2 млрд руб., то по итогам 2018 г. они составили 3668,6 млрд руб., или 109,2\% от уровня 2017 г. в сопоставимых ценах. Доля расходов на здравоохранение также выросла с 8,8 до 9,8\% благодаря увеличению финансирования по данному направлению на $14,2 \%$ в реальном выражении. Траты на национальную оборону и национальную экономику снижались, а расходы на национальную безопасность и правоохранительную деятельность почти не изменились. Таким образом, в 2018 г. была продемонстрирована смена приоритетов бюджетной политики, заявленная Президентом и утвержденная Законом «О федеральном бюджете...» на очередной трехлетний период.

Незапланированный рост доходов обеспечил профицит консолидированного бюджета РФ и бюджетов государственных внебюджетных фондов в размере более 3 трлн руб., т.е. почти $3,0 \%$ ВВП. Около 90\% профицита традиционно приходится на долю федерального бюджета.

Существенный рост цен нефти при осторожном бюджетном планировании вновь способствовал значительному улучшению показателей федерального бюджета РФ. Доходы федерального бюджета выросли на четверть в реальном выражении: с 15 088,9 млрд до 19 454,9 млрд руб., из которых $46 \%$ пришлось на долю нефтегазовых доходов. Объем расходов при этом практически не изменился, а в сопоставимых ценах оказался на 1,1\% ниже уровня 2017 г. Вновь образовался значительный профицит федерального бюджета, что позволило возобновить пополнение Фонда национального благосостояния в соответствии с новым бюджетным правилом.

Рисунок 4 демонстрирует резкий рост нефтегазовых доходов в 2018 г. - почти в два раза. Основная компонента - поступления от налога на добычу полезных ископаемых в виде углеводородного сырья - выросла на 45,2\% в сопоставимых ценах 2017 г. 
Вывозные таможенные пошлины на сырую нефть и товары, выработанные из нефти, выросли более чем на $50 \%$ в реальном выражении. Это увеличение произошло не только за счет роста цен на нефть (хотя он остается основным фактором), но и благодаря увеличению добычи нефти и газа на 1,7\%, а также - экспорта на 2,9\% (в натуральных величинах).

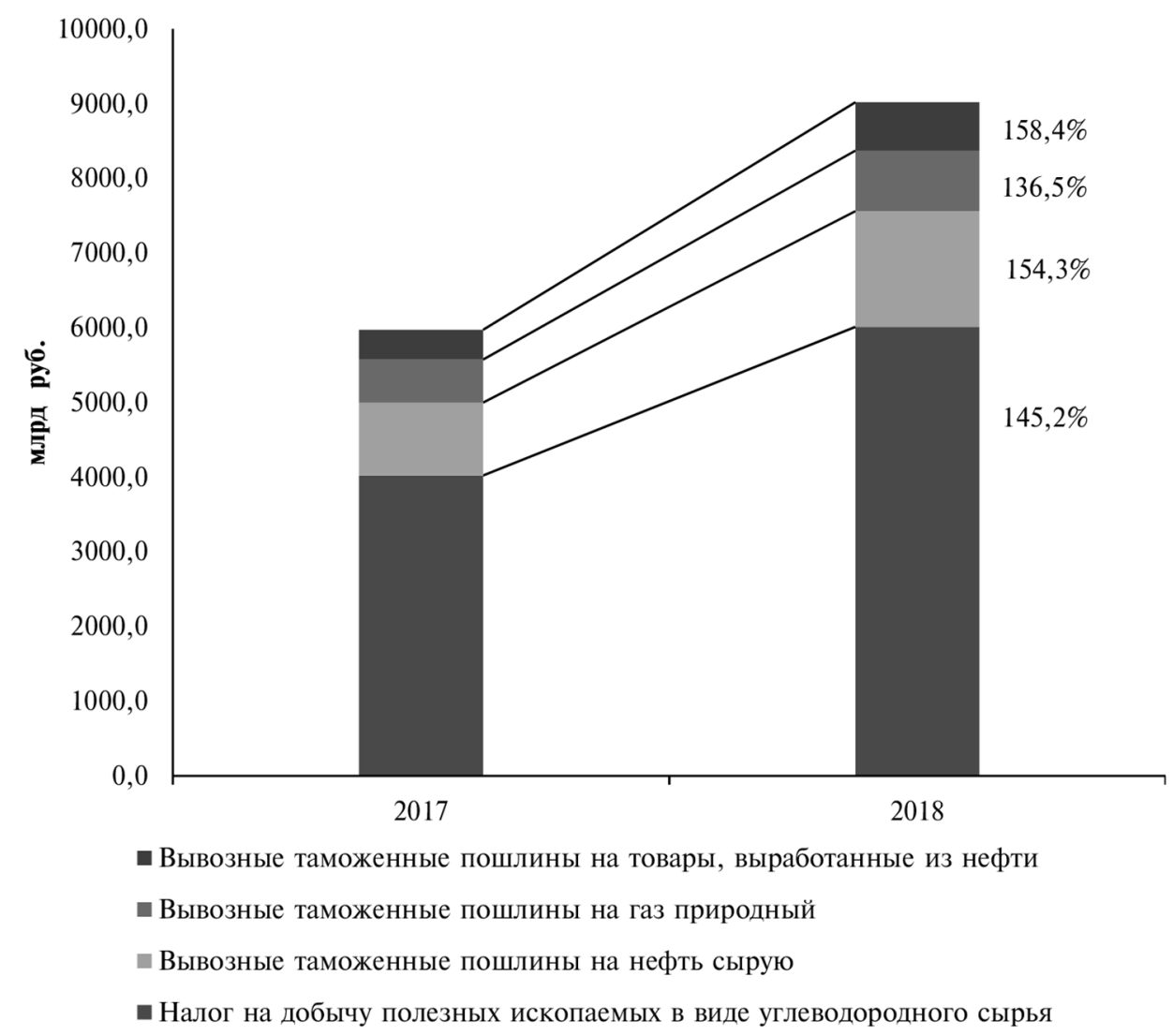

Рис. 4. Динамика и структура нефтегазовых доходов федерального бюджета в 2017-2018 г2., млрд руб., в \% (в сопоставимых ценах 2017 г.)

Увеличение объемов добычи, реализации (прежде всего на экспорт) и переработки нефти в стоимостном выражении также обеспечило федеральному бюджету заметный прирост поступлений по налогу на прибыль организаций (в части, зачисляемой в федеральный бюджет). Сумма поступлений выросла почти на 30,0\% в сопоставимых ценах 2017 г. При этом доходы в виде налога на прибыль организаций консолидированных групп налогоплательщиков выросли в 1,6 раза.

Расходы федерального бюджета остались практически на том же уровне, что и в 2017 г. В сопоставимых ценах 2017 г. их объем даже сократился на $1,1 \%$ (табл. 5). 
Таблииа 5

Структура и динамика расходов федерального бюджета в 2018 г.

\begin{tabular}{|c|c|c|c|}
\hline Статьи расходов & Млрд руб. & В \% & $\begin{array}{c}2018 \text { г. к } 2017 \text { г. } \\
\text { в сопоставимых } \\
\text { ценах, в \% }\end{array}$ \\
\hline Расходы & 16712,9 & 100,0 & 98,9 \\
\hline Общегосударственные вопросы & 1257,0 & 7,5 & 105,1 \\
\hline Национальная оборона & 2827,0 & 16,9 & 96,3 \\
\hline $\begin{array}{l}\text { Национальная безопасность и правоохранитель- } \\
\text { ная деятельность }\end{array}$ & 1971,6 & 11,8 & 99,9 \\
\hline Национальная экономика & 2402,1 & 14,4 & 94,9 \\
\hline Жилищно-коммунальное хозяйство & 148,8 & 0,9 & 121,0 \\
\hline Охрана окружающей среды & 116,0 & 0,7 & 122,0 \\
\hline Образование & 722,6 & 4,3 & 114,2 \\
\hline Культура, кинематография & 94,9 & 0,6 & 102,8 \\
\hline Здравоохранение & 537,3 & 3,2 & 118,7 \\
\hline Социальная политика & 4581,8 & 27,4 & 89,2 \\
\hline Физическая культура и спорт & 64,0 & 0,4 & 64,7 \\
\hline Средства массовой информации & 88,4 & 0,5 & 103,3 \\
\hline $\begin{array}{l}\text { Обслуживание государственного и муниципаль- } \\
\text { ного долга }\end{array}$ & 806,0 & 4,8 & 110,4 \\
\hline $\begin{array}{l}\text { Межбюджетные трансферты общего характера } \\
\text { бюджетам бюджетной системы РФ }\end{array}$ & 1095,4 & 6,6 & 134,6 \\
\hline $\begin{array}{l}\text { Справочно: } \\
\text { Профицит (+) / Дефицит (-) }\end{array}$ & 2742,0 & & \\
\hline
\end{tabular}

Номинально сократились расходы на национальную оборону, национальную экономику, социальную политику и физическую культуру. Расходы на национальную безопасность номинально выросли, но в сопоставимых ценах 2017 г. оказались на 0,1\% меньше, чем в предыдущем периоде. Наиболее заметным стало снижение социальных расходов. Год от года они увеличивались, несмотря на общий секвестр, обусловленный спадом в российской экономике 2015-2016 гг. В 2018 г. расходы на социальную политику сократились с 4 992,0 до 4 581,8 млрд руб., в сопоставимых ценах 2017 г. это снижение оценивается в 10,8\%. В результате такого падения доля расходов на социальную политику в общей сумме расходов федерального бюджета сократилась с 30,4 до 27,4\%. Снижение данных расходов в сравнении с предыдущим периодом обусловлено тем, что в 2017 г. производилась единовременная выплата пенсионерам, которая не осуществлялась в 2018 г. Таким образом, объем расходов на социальную политику номинально сопоставим 
с аналогичным показателем 2016 г., хотя в реальном выражении (с учетом инфляции за 2017-2018 гг.) он меньше на 6,4\%.

Если бы не произошло сокращения расходов на социальную политику, то увеличение финансирования по статьям «Образование» и «Здравоохранение» в общей сложности обеспечило бы целый процентный пункт прироста итоговой суммы расходов федерального бюджета. В целом доля расходов на образование и здравоохранение в структуре федерального бюджета выросла с 6,4 до 7,5\%.

Целых 34,6\% роста (в сопоставимых ценах 2017 г.) отмечается по статье «Межбюджетные трансферты общего характера бюджетам бюджетной системы Российской Федерации». Удельный вес этих расходов вырос с 4,8 до 6,6\%. Представляется, что такое увеличение связано с задачей выполнения указов Президента от 2012 г.

Также в 2018 г. значительные темпы прироста (более 20\%) показали статьи расходов, удельный вес которых невелик, поэтому значимого эффекта на результат не произошло. К ним относятся расходы на жилищно-коммунальное хозяйство и охрану окружающей среды.

Еще в 2017 г. федеральный бюджет был сведен с дефицитом в размере более 1 трлн руб. Однако по итогам 2018 г. профицит федерального бюджета составил 2,7 трлн руб. (2,6\% ВВП).

Бюджетно-налоговая политика в России носит преимущественно проциклический характер. При этом достаточных обоснований для проведения сдерживающей политики в периоды спада деловой активности не отмечается. По крайней мере в 2015-2018 гг. спад и медленный выход из рецессии не столь значительно влияли на доходы бюджета расширенного правительства, поскольку основной удар принял на себя федеральный бюджет.

Основной вклад в стимулирование ВВП, по оценкам, вносят расходы на национальную экономику. Их снижение (относительно выпуска) в пользу увеличения расходов на социальную сферу отрицательно влияет на экономический рост. Это подтверждают данные за 2018 г.

\section{Список литературы}

1. Vegh C.A. Fiscal Policy in Emerging Markets: Procyclicality and Graduation // NBER Reporter. 2015. Iss. 4. P. 8-12.

2. Batini N., Eyraud L., Weber A. A Simple Method to Compute Fiscal Multipliers / IMF. 2014. WP/14/93, P. 1-33.

3. Эффективность госрасходов в России / Центр макроэкономических исследований Сбербанка России. 13.01.2011. - 18 с. 


\section{FISCAL POLICY OF RUSSIA IN THE PERIOD OF ECONOMIC GROWTH SLOWDOWN AND THE RESULTS OF 2018}

Traditionally, one of the objectives of fiscal policy is smoothing the effects of fluctuations in business activity. In this connection, in the periods of recession, there should be a stimulating policy, and in the periods of recovery - restraining policy. Fiscal policy in Russia, as it's shown in the article, is primarily procyclical. During the 2015 recession, according to the calculations using multipliers, government spending contributed to the reduction of GDP rather than to the support of its growth. Later, despite a significant increase in the revenues of the expanded government budget and the shift in priorities from defense and security financing to social sphere, the effect of the increase in budget expenditures turned out to be negative. The article also discusses the state of the budget sphere following the results of 2018 , which showed the restoration of economic growth.

Keywords: fiscal policy, consolidated budget of the Russian Federation and budgets of state extra-budgetary funds, multiplier, federal budget, economic policy, economic growth, economic cycle

JEL: E62, E64, H50, H60

Дата поступления - 06.03.2019 г.

\section{БУКИНА Ирина Сергеевна}

кандидат экономических наук, ведущий научный сотрудник;

Федеральное государственное бюджетное учреждение науки Институт экономики Российской академии наук / Нахимовский проспект, д. 32, г. Москва, 117218.

e-mail: bis.email@gmail.com

\section{BUKINA Irina S.}

Cand. Sc. (Econ.), Senior Researcher;

Federal State Budgetary Institution of Science Institute of Economics of Russian Academy of Sciences / 32, Nakhimovsky Av., Moscow, 117218.

e-mail: bis.email@gmail.com

\section{Для цитирования:}

Букина И. Бюджетно-налоговая политика России в период замедления экономического роста и итоги 2018 г. // Федерализм. 2019. № 1. С. 86-99. 